\title{
Sistem E-Learning Terintegrasi Web Sebagai Solusi Dalam Meningkatkan Kualitas Pendidikan Dan Pembelajaran Mahasiswa
}

\author{
Abdurrasyid ${ }^{1}$, Indrianto ${ }^{2}$, Meilia Nur Indah Susanti ${ }^{3}$ \\ Universitas Muhammadiyah Tangerang / Fakultas Teknik, \\ Program Studi Informatika \\ Jl. Perintis Kemerdekaan 1/33 Cikokol Kota Tangerang TLP. 55793251, 55772949, 55793802, 55736926 \\ e-mail: rasyid@sttpln.ac.id, indrianto@sttpln.ac.id, meilia@sttpln.ac.id
}

\begin{abstract}
ABSTRAK
Media pembelajaran merupakan salah satu bagian yang cukup penting dalam pelaksanaan perkuliahan, mengingat beragam kendala dan tantangan yang akan ditemukan selama masa kuliah. Peranan media pembelajaran sering kali terabaikan, sehingga mahasiswa tidak jarang merasa jenuh dan bosan dalam proses perkuliahan yang mengakibatkan kurang optimalnya hasil yang diperoleh. Terlebih jika hasil perkuliahan yang hanya sebatas interaksi di kelas kurang memanfaatkan media yang sebenarnya telah ada justru kurang maksimal.

Perancangan web aplikasi media pembelajaran e-learning merupakan salah satu solusinya, dengan menggunakan Java berbasis web dan database MySql dalam pembuatannya. Dan menggunakan metode pendekatan SDLC dalam penerapannya, serta dikuatkan dengan adanya kuesioner dalam proses pembuatan aplikasi ini.

Perancangan web aplikasi e-learning ini bertujuan untuk memudahkan proses perkuliahan yang sebenarnya dapat dilakukan dimana dan kapan saja dengan data materi dan kuis mata kuliah yang lebih aman dan efektif tersimpan di dalam database aplikasi.
\end{abstract}

Kata kunci: Media Pembelajaran,E-Learning, Java, Web aplikasi, MySql

\begin{abstract}
Learning media is one fairly important part in the implementation of lectures, given the variety of obstacles and challenges that would be found during college. The role of instructional media is often overlooked, so that students not uncommon to feel tired and bored in a lecture which resulted in less than optimal results. Especially if the result of courses that only limited interaction in the classroom less use of media that actually existed even less than the maximum.

Web design media applications E-learning is one solution, using a web-based Java and MySQL database in the making. And using SDLC approach in its implementation, and strengthened by the questionnaire in the process of making this application.

Designing web application e-learning is intended to facilitate the process of actual lectures can be done anywhere and anytime with the data material and quiz subjects more safely and effectively stored in the application database.
\end{abstract}

Keywords: Learning Media, E-Learning, Java, Web application, MySQI 


\section{PENDAHULUAN}

Berdasarkan analisa yang dilakukan oleh industri global pada tahun 2008 bahwa biaya yang dikeluarkan untuk mendapatkan layanan e-learning total di seluruh dunia mencapai US\$ 52.6 miliar, ini menandakan perkembangan e-learning dalam berbagai aspek sangatlah cepat dan menjadi hal yang sangat berpotensi untuk terus dikembangkan, khususnya dalam kegiatan pendidikan tingkat tinggi.

Pada penelitian yang dilakukan oleh Sridharan, Deng, \& Corbitt (2010) ada tiga hal yang membuat E-Learning menjadi kurang efektif yakni kurangnya pemahaman akan teknologi yang digunakan, kurangnya penggunaan sistem manajemen belajar yang populer serta objek belajar yang terus up to date, disamping itu E-Learning tidak hanya sebatas menyimpan slide perkuliahan di web (Cornford and Pollock, 2003; Kim and Lee, 2007).

Istilah e-learning atau kegiatan pembelajaran berbasis elektronik merupakan istilah yang sebenarnya sudah lama di kemukakan, pada kenyataannya system elearning yang ada hanya memenuhi salah satu persyaratan komponen fundamental dalam pengembangan e-learning yaitu substansi dan konten, disisi lain seiring perkembangan teknologi yang tidak pernah berhenti berinovasi dan penelitian para pakar tentang bagaimana menerapkan e-learning yang paling tepat membuat e-learning terus popular hingga saat ini.

Perguruan Tinggi dituntut untuk dapat menghasilkan sumberdaya manusia yang berkualitas, melalui sistem pembelajaran yang inovatif memiliki strategi dan teknik yang menantang, mendorong mahasiswa untuk berpikir kritis bereksplorasi, berkreasi dan bereksperimen dengan memanfaatkan aneka sumber, serta memiliki mekanisme untuk memonitor, mengkaji, dan memperbaiki secara periodik kegiatan perkuliahan, penyusunan materi perkuliahan, serta penilaian hasil belajar, hal ini tercermin pada poin dokumen akreditasi program studi.

$$
\text { Tuntutan tersebut memaksa }
$$

perguruan tinggi untuk terus berinovasi dengan memanfaatkan teknologi yang ada serta penerapan konsep cara belajar yang mampu memaksa mahasiswa untuk dapat belajar mandiri tanpa harus diawasi namun tetap dapat termonitor dengan baik dan dapat dinilai oleh dosen, penyamaan silabus untuk matakuliah - matakuliah yang diampu oleh lebih dari satu dosen merupakan permasalahan yang harus diselesaikan sehingga ada keseragaman baik silabus, satuan acara perkuliahan, hingga materi ajar adapun soal baik dalam bentuk quiz ataupun tugas yang diberikan kepada mahasiswa dapat di atur oleh dosen paralel tersebut apakah mau disamakan atau tidak sehingga sangat memberikan fleksibilitas namun tidak menghilangkan nilai-nilai pembelajaran yang baik.

E-learning dianggap dapat memberikan solusi terhadap permasalahan permasalahan diatas disamping penelitian sebelumnya banyak merekomendasikan menggabungkan kegiatan manajemen pengetahuan yang sistematis dan elemen metadata dalam menggambarkan sumber belajar (Demidova et al, 2005;.. Yang et al, 2006a, b). Nonaka dan Toyamma (2003) merekomendasikan aktifitas menangkap, memunculkan, pengorganisasian, mengambil, otentikasi, dan menggunakan kembali sumber daya yang tersedia kedalam e-learning untuk dapat meningkatkan kualitas pendidikan dan pembelajaran.

\section{METODE PENELITIAN}

SDLC (System Development Life Cycle) adalah sebuah siklus hidup pengembangan perangkat lunak yang terdiri dari beberapa tahapan yang penting dalam keberadaan perangkat lunak yang dilihat dari segi pengembangannya.

SDLC terdiri dari beberapa tahapantahapan berdasarkan analisa kebutuhan yang ada. Dimulai dari analisa kebutuhan perangkat lunak yang akan dibuat terlebih dahulu, desain dari kebutuhan tersebut untuk mempermudah dalam pengerjaannya. Kemudian segala kebutuhan diimplementasikan dengan dua tahap yaitu tahap analisa dan tahap evaluasi (user acceptance test). Setelah melakukan implementasi, maka proses tersebut akan dikembalikan lagi ke dalam tahap desain 
untuk pengembangan kembali perangkat lunak ke versi yang terbaru.

Pada hal ini penulis menggunakan model waterfall dari proses SDLC, karena waterfall merupakan SDLC yang bersifat natural. Urutan SDLC waterfall bersifat serial dari proses perencanaan, analisa, desain, dan implementasi pada sistem. Model waterfall melakukan pendekatan secara sistematis dan urut mulai dari level kebutuhan sistem laju menuju ke tahap analysis, design, coding, testing, maintenance.

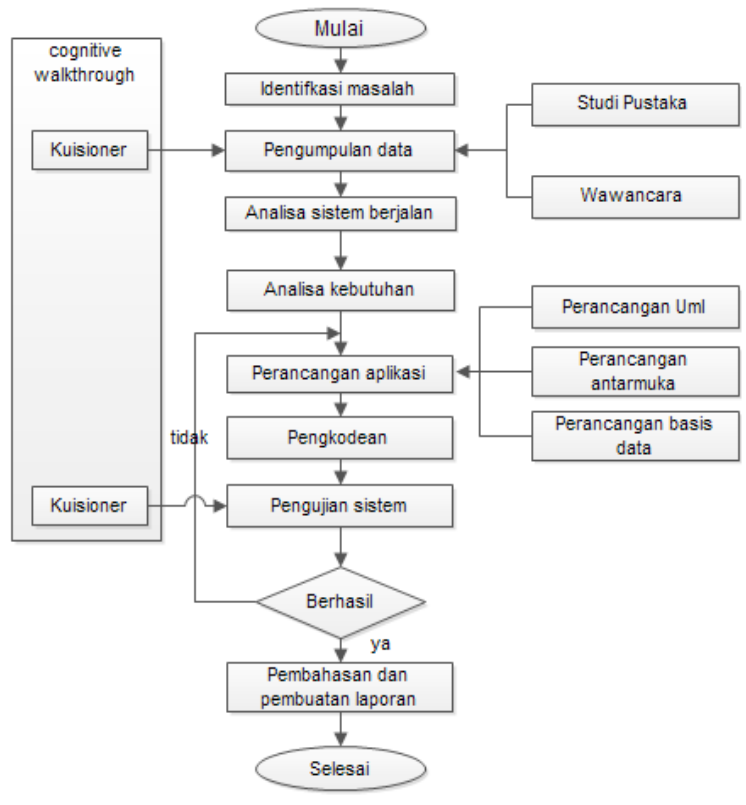

Gambar 1 Diagram penelitian

\section{HASIL DAN ANALISIS}

Dari sistem berjalan yang ada diperlukannya sebuah website aplikasi elearning, agar dapat memudahkan proses perkuliahan dan transfer knowledge dari dosen ke mahasiswa di luar proses belajar di kelas. Cara kerjanya yaitu mahasiswa \& dosen mata kuliah cukup dengan berinteraksi melalui aplikasi e-learning yang telah ada melalui website dalam hal masalah pembagian materi serta pengerjaan tugas-tugas yang ada.

Dari analisa yang didapatkan dari sistem berjalan, maka dibuatlah analisa akan kebutuhan sistem yang dirancang, berupa aplikasi yang dapat dijalankan pada web aplikasi e-learning. diusulkan :

Berikut alur kerja sistem yang

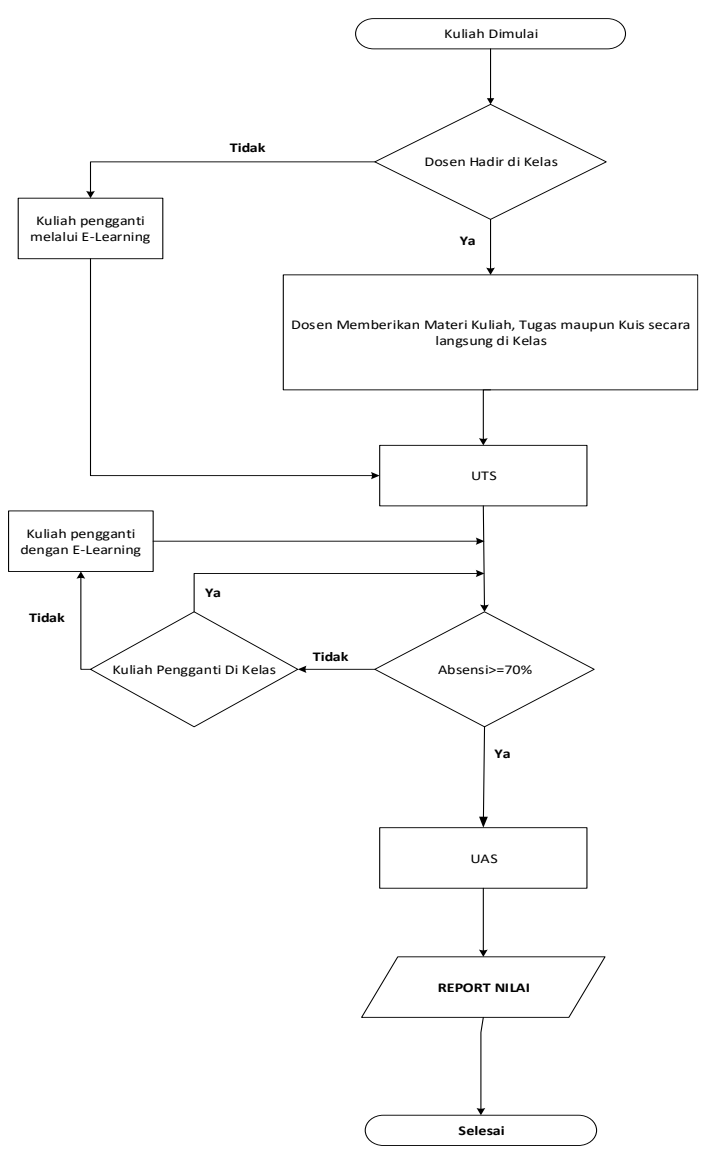

Gambar 2. Alur kerja sistem usulan

Dalam mengembangkan aplikasi ini, penulis mengambil format tampilan \& isi seperti yang banyak digunakan pada aplikasi e-learning pada khususnya yang kemudian disesuaikan dengan kebutuhan user yaitu dosen mata kuliah \& mahasiswa yang masing-masing memiliki akun, seperti pada perancangan UML berikut ini: 


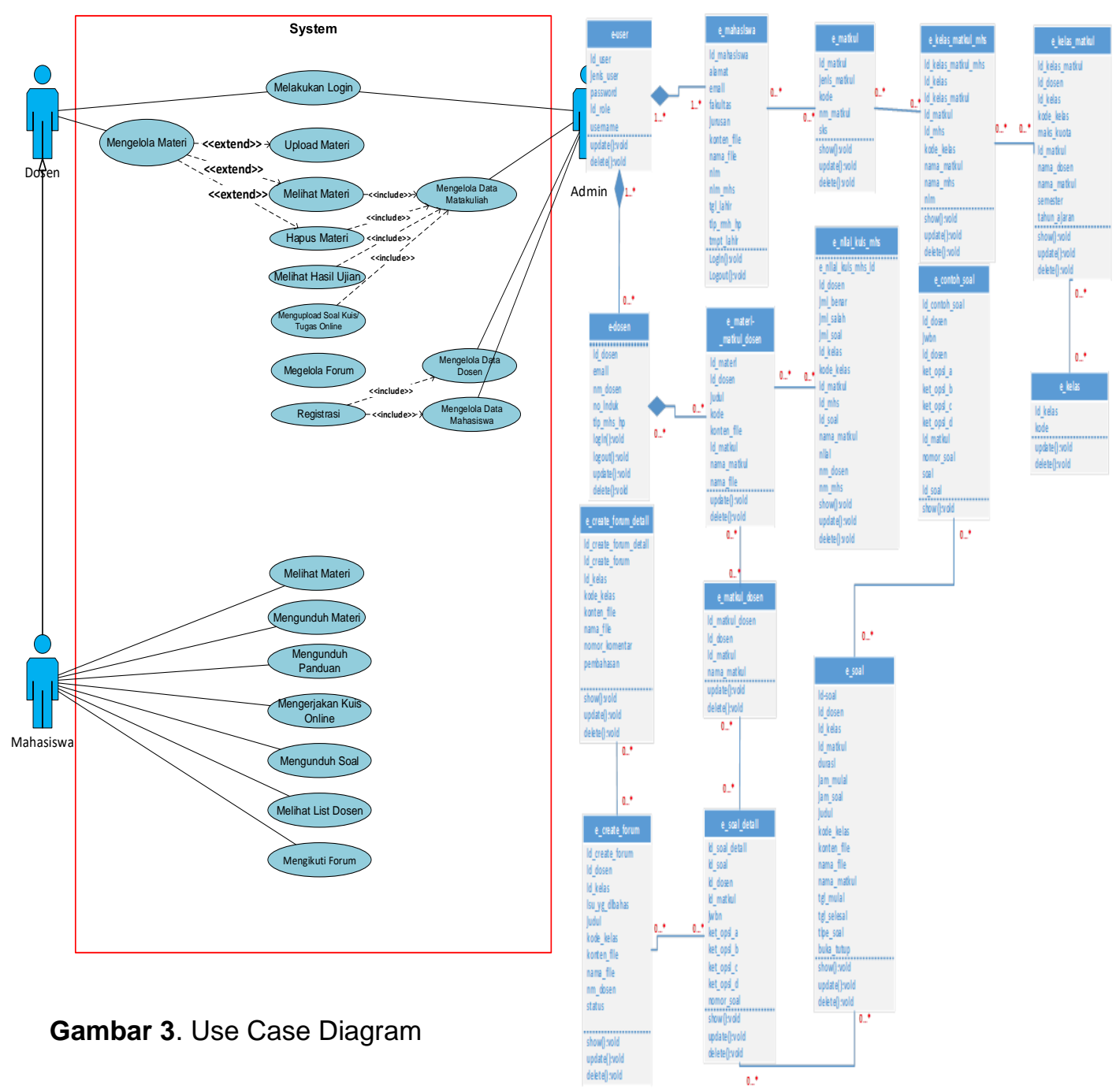

Gambar 4. Class Diagram

Berdasarkan perancangan penelitian yang telah dilakukan, berikut beberapa hasil tampilan dari e-learning yang ada: 


\section{Halaman Login}

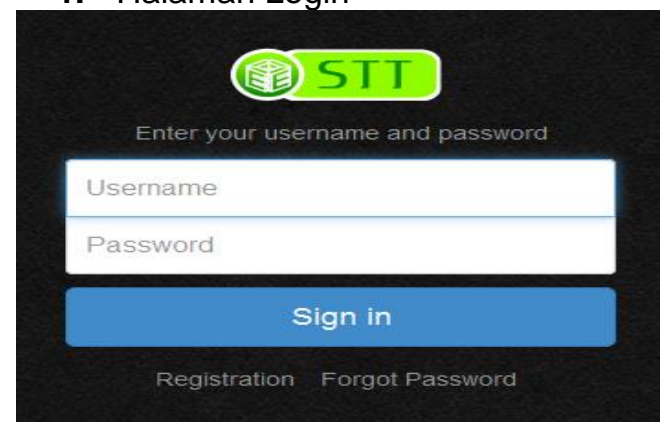

Gambar 5. Halaman Login

Merupakan tampilan awal ketika ingin masuk dan menggunakan aplikasi $e$ learning, dalam hal ini yang bisa login hanya yang sudah terdaftar lebih dahulu.

\section{Menu Registrasi}

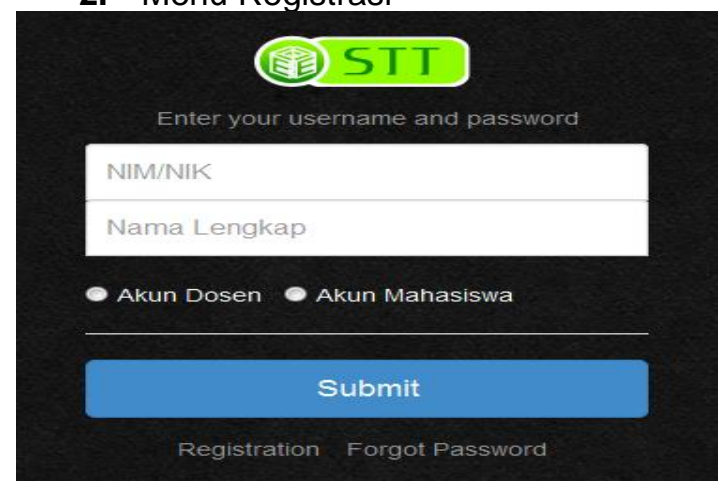

Gambar 6. Halaman Registrasi

Di halaman inilah disediakan fasilitas untuk mendaftar atau registrasi untuk kemudian dapat menggunakan fitur $e$ learning yang ada. Untuk selanjutnya setiap permintaan registrasi akun user yang baru akan menunggu persetujuan dari admin yang ada.

3. Menu Beranda Mahasiswa

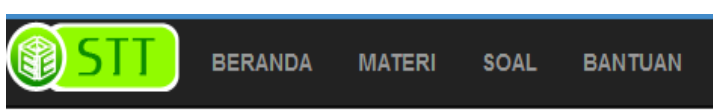

UTS01 - Ujian Tengah Semester - Ujian Tengah Semester KU2 - Kuis Algoritma 2 - Kuis Dibuka

\section{5 (C) ELEARNING}

\section{Gambar 7. Halaman Beranda Mahasiswa}

Menu beranda yang ada pada mahasiswa dirancang sedikit lebih ringkas dibanding menu \& fasilitas yang ada pada akun dosen.

Pada halaman utama ini juga kami senantiasa menampilkan notifikasi ketika ada tugas, kuis maupun grup diskusi yang telah diberikan oleh dosen, sehingga para mahasiswa diharapkan akan selalu tau jika ada informasi tugas terbaru.

Beberapa fitur yang ada yaitu:

a. Menu Materi yang berfungsi untuk melihat tampilan list materi kuliah dan bahan ajar yang telah disiapkan oleh para dosen.

b. Menu Soal yang fungsinya untuk melihat tampilan nilai dan hasil dari tugas maupun kuis yang sebelumnya telah dikerjakan oleh si mahasiswa.

c. Menu Bantuan berisi tata cara atau panduan penggunaan aplikasi yang ditujukan kepada mahasiswa.

4. Menu Beranda Dosen

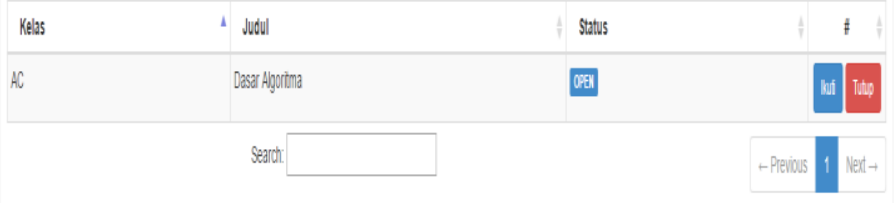




\section{Gambar 8. Halaman Beranda Dosen}

Menu beranda pada dosen dirancang untuk memudahkan fungsi dan tugas dari para dosen dalam proses belajar mengajar. Mulai dari proses menyiapkan materi dan bahan ajar, hingga pada pembuatan soal dan forum diskusi.

Beberapa fitur yang ada yaitu:

a. Menu Mata Kuliah Terdapat icon "Lihat Materi" untuk menampilkan detail tentang materi perkuliahan yang pernah dipublikasikan oleh dosen. Juga terdapat icon "Lihat Hasil" untuk menampilkan list dari tugas maupun kuis yang pernah dibuat oleh dosen.

b. Menu Materi

Terdapat tombol pilihan +Materi untuk kemudian melakukan proses penambahan materi. Setelah kita memilih tombol tersebut, maka akan muncul Form Tambah Materi. Pada form ini terdapat beberapa field yang harus diinput ketika ingin melakukan penambahan materi.

c. Menu Forum

Pada menu ini digunakan oleh dosen untuk kemudian dapat membuat forum grup diskusi dari masing-masing kelas yang diajarkan.

d. Menu Soal

Menu ini khusus berfungsi untuk kemudian melakukan penambahan soal tugas maupun kuis.

e. Menu Bantuan berisi tata cara atau panduan penggunaan aplikasi yang ditujukan kepada mahasiswa.

Pengumpulan data dilakukan dengan cara diskusi langsung dengan beberapa orang mahasiswa maupun dosen kampus. Beberapa dari hasil masukan para calon pengguna kemudian kami jadikan fitur yang ada pada aplikasi ini.
Tabel 1. Tabel Perbandingan Sistem

\begin{tabular}{|c|c|c|c|}
\hline No. & \multicolumn{2}{|c|}{$\begin{array}{c}\text { Sistem Yang } \\
\text { Berjalan }\end{array}$} & $\begin{array}{c}\text { Usulan Sistem } \\
\text { Baru }\end{array}$ \\
\hline 1. & $\begin{array}{l}\text { Proses tra } \\
\text { knowledge h } \\
\text { dapat terjadi } \\
\text { kelas jika d } \\
\text { dan mahas } \\
\text { datang } \\
\text { bertemu langsu }\end{array}$ & $\begin{array}{l}\text { isfer } \\
\text { inya } \\
\text { di } \\
\text { sen } \\
\text { swa } \\
\text { dan } \\
\text { ig. }\end{array}$ & $\begin{array}{l}\text { Proses trans } \\
\text { knowledge dar } \\
\text { dilakukan mela } \\
\text { sistem aplikasi } \\
\text { learning yang tel } \\
\text { dibuat namun tan } \\
\text { mengurangi urger } \\
\text { dari pros } \\
\text { pembelajaran } \\
\text { kelas. }\end{array}$ \\
\hline 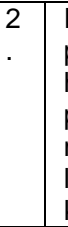 & \begin{tabular}{lr}
\multicolumn{2}{l}{ Pelaksanaan } \\
perkuliahan \\
harus $\quad$ melalui \\
proses $\quad$ tatap \\
muka recara \\
langsung \\
kelas.
\end{tabular} & $\begin{array}{l}\text { Pela } \\
\text { perk } \\
\text { dilak } \\
\text { dim } \\
\text { onlir }\end{array}$ & $\begin{array}{l}\text { ksanaan } \\
\text { kuliahan dapat } \\
\text { ana saja secara } \\
\text { le. }\end{array}$ \\
\hline 1 & $\begin{array}{l}\text { Materi } \\
\text { perkuliahan } \\
\text { yang ada di } \\
\text { kelas pada } \\
\text { dasarnya tidak } \\
\text { semua } \\
\text { mahasiswa } \\
\text { dapat mencatat } \\
\text { dan } \\
\text { menyimpannya } \\
\text { dengan baik. }\end{array}$ & $\begin{array}{l}\text { Mat } \\
\text { data } \\
\text { kuis } \\
\text { lebil } \\
\text { kare } \\
\text { ters } \\
\text { data } \\
\text { men } \\
\text { ingir }\end{array}$ & $\begin{array}{l}\text { eri perkuliahan, } \\
\text { tugas beserta } \\
\text { di dalam aplikasi } \\
\text { bersifat aman } \\
\text { ima datanya } \\
\text { anase, juga akan } \\
\text { nudahkan ketika } \\
\text { dibuka lagi. }\end{array}$ \\
\hline
\end{tabular}

Beberapa keuntungan dan kelebihan yang bisa diperoleh dari penggunaan aplikasi ini yaitu sistem pembelajaran yang ada jadi lebih tersusun rapid dan aman karena sudah berada di dalam sistem database yang ada.

Dengan sistem ini pula maka proses pembelajaran kini tidak lagi hanya terpusat di kelas melainkan juga bisa di lakukan di luar kelas dengan sistem jarak jauh yang sifatnya online.

\section{KESIMPULAN}

Dari hasil penelitian yang dilakukan dari tahap awal hingga proses pengujian, dengan adanya aplikasi e-learning disimpulkan bahwa :

a. Dengan adanya aplikasi e-learning ini, mahasiswa diharapkan tidak perlu takut ketinggalan materi dan tugas mata kuliah yang ada karena akan tersimpan pada database aplikasi. 
b. Dengan adanya aplikasi e-learning, diharapkan dapat membantu jika dalam kondisi jauh, libur kuliah maupun kendala lain seperti sakit, akses pembelajaran tetap dapat dilakukan dimana saja secara online.

c. Aplikasi E-learning ini diharapkan dapat membantu proses kegiatan belajar-mengajar menjadi lebih fleksibel. Juga dengan adanya aplikasi ini, maka bisa dijadikan sebagai metode alternatif dalam proses belajar-mengajar.

d. Aplikasi e-learning juga diharapkan bisa dijadikan sebagai wadah untuk lebih banyak lagi interaksi dan diskusi antara dosen an mahasiswa yang diharapkan mampu meningkatkan mutu pendidikan dan minat belajar yang ada.

\section{REFERENSI}

\section{Journal:}

[1] Cantoni, L. (2004). World Conference on Educational Multimedia, Hypermedia \& Telecommunications. AACE , 50-5.

[2] Cornford, J., \& Pollock, N. (2003). Putting the University Online: Information, Technology and Organisational Change. Buckingham: Open University Press.

[3] Critical issues for e-learning delivery: what may seem obvious is not always put into practice. (2008). Journal of Computer Assisted Learning , 24, 433-45.

[4] Demidova, E., Ternier, S., Olmedilla, D., Dual, E., Dicerto, M., Stefanov, K., et al. (2005). Integration of heterogeneous information sources into knowledge resource management system for lifelong learning. Proceedings of the Ten CompetenceWorkshop. Manchester.

[5] Global Industry Analysts, I. (2008). elearning: A Global Strategic Business Report. Retrieved Juni 05, 2016, from www.strategyr.com/pressMCP-4107.asp

[6] J. Olin, C., John, R. B., Pieter, J. M., \& Arthur, J. B. (2002). The Effectiveness of Learning Simulations for Electronic
Laboratories. Journal Of Engineering Education , 81-87.

[7] Kamarga, H. (2002). Belajar Sejarah Melalui E-Learning: Alternatif Mengakses Sumber Informasi Kesejarahan. Jakarta: Inti Media.

[8] Koran, J. K. (2002). Aplikasi 'E-Learning' Dalam Pengajaran Dan Pembelajaran Di Sekolah-Sekolah Malaysia: Cadangan Perlaksanaan Pada Senario Masa Kini,. Malaysia: Pasukan Projek Rintis Sekolah Bestari Bahagian Teknologi Pendidikan Kementerian Pendidikan Malaysia.

[9] Marc, R. (2001). E-Learning: Strategies for Delivering Knowledge in the Digital Age. USA: The McGraw Hill Companies, Inc.

[10] Nonaka, I., \& Toyamma, R. (2003). The knowledge-creating theory revisited: knowledge creation as synthesizing process. KnowledgeManagement Research and Practice , 1, 2-10.

[11]Ojekun, A. A., \& Ojedokun. (2003). Transforming the library into a teachinglearning laboratory: the case of University of Botswana Library. Campus Wide Information System , 20 No. 1, 25-31.

[12] Robert, P., \& Piper, J. (2015, Maret 23). Ukessays.com. Retrieved Juni 9, 2016, from www.ukessays.com: https://www.ukessays.com/essays/educat ion/ict-in-developing-and-developedcountries-education-essay.php 